\title{
How do SMEs use support services during their internationalisation process: A comparative study of French traditional SMEs and INVs in Asia
}

\author{
Nathalie Belhoste \\ Grenoble Ecole de Management, France
}

\author{
Rachel Bocquet, Véronique Favre-Bonté and \\ Frédéric Bally \\ University Savoie Mont Blanc, France
}

\begin{abstract}
This article integrates research on the internationalisation processes of small and medium sized enterprises (SMEs) and export assistance services to investigate how such firms use support services drawing upon a large, qualitative study of 32 French traditional SMEs and international new ventures (INVs) that have entered Asia. Our key contribution is to consider the time to internationalisation (gradual or rapid) and the stage of internationalisation (entrance or intensification) rather than export intensity alone, and to examine how support services can help SMEs internationalise. The identification of different configurations of uses leads to the development of theoretical propositions that extend existing models pertaining to support services and firm internationalisation. These findings have several important managerial implications for support services to target their offer more precisely to two types of SMEs; they also provide useful guidance for SMEs to determine which tailor-made offerings from private and public actors are most applicable to their internationalisation efforts.
\end{abstract}

\section{Keywords}

international new ventures, internationalisation process, internationalisation support services, traditional small medium-sized enterprises 
Small and medium-sized enterprises (SMEs) are critical to the competiveness of advanced, industrialised countries; their growth is driven by many factors among which internationalisation plays a significant role (Love and Roper, 2015; Wright et al., 2015). Hence, their potentially limited ability to expand internationally represents a concern for policymakers. In France, for example, relatively few SMEs maintain international operations (Bonnet and Lavergne, 2015), particularly in Asian markets. Yet, public and private support for the internationalisation of SMEs has increased significantly in France over the past 20 years, suggesting that the influence of these types of support services may be less than adequate.

To clarify how public and private support services, that is, specialised organisations or actors that help companies expand internationally by providing advice, contacts, training or support, might encourage the internationalisation efforts of SMEs, we propose considering two concepts. First, the concept of time to internationalisation - gradual or rapid - to capture how soon after inception the firm begins to internationalise (Hilmersson et al., 2017). Prior international business research establishes that SMEs can reach distant markets by adopting either a gradual or a rapid process, referring to them as traditional $S M E s^{1}$ or international new ventures (INVs), respectively (Hilmersson et al., 2017). Second, we consider the concept of stage, which addresses whether the firm is in its early stages of international operations (entrance) or in later stages (intensification) (Efrat and Shoham, 2012). Few existing studies address the role of support services as key resources for overcoming barriers to these two internationalisation processes (Catanzaro et al., 2015; Leonidou et al., 2010). Existing studies of the SME internationalisation process consider the role of networks as a kind of informal support service (Ojala, 2009), but without investigating their relationships with other formal types of support, such as internationalisation support services. Furthermore, the extant evidence regarding support services is limited to the initial decision in terms of international expansion without addressing later stages when the process intensifies (Freixanet, 2012).

To address this gap, we integrate previous findings on the internationalisation processes of SMEs and export assistance services to identify uses of support services by SMEs, depending on their time to internationalisation and the stage of their internationalisation process. Consequently, our main research questions focus upon: 'How do SMEs use support services during their internationalisation processes?' and, 'do their uses differ according to their time to internationalisation (gradual or rapid) or their stages (entrance or intensification)?' To address these questions, we use a qualitative research design investigating SMEs in the French Auvergne Rhône-Alpes (AURA) region. We define SMEs as firms that employ no more than 249 employees, with an annual turnover of less than $€ 50$ million and a maximum balance sheet of $€ 43$ million (European Commission, 2015). Among the heterogeneous SMEs in this region, and in order to have a homogeneous unit of analysis, we identified 32 SMEs in four sectors (i.e. mecatronic, healthcare, clean tech and outdoor) that entered Asia gradually or rapidly, measured by the time to internationalisation (Hilmersson et al., 2017) with or without support from publicly available services. We also consider the point in time when internationalisation commenced (Hilmersson et al., 2017), distinguishing between three time periods of internationalisation to generate an appropriate comparison.

This article offers three key advances summarised in a set of propositions. First, the contextualised approach to the use of support services over time reveals that these uses differ according to two relevant elements: time to internationalisation and the stage of the process. We thus offer an explanation for the contradictory results in previous research on support service use ${ }^{2}$ (Yoo et al., 2012), such that they can be addressed by acknowledging the influence of the distinct processes and stages. Second, this study complements internationalisation support services research that focuses almost exclusively on public forms of support by explicitly addressing the role of private services. We uncover distinct, complementary uses of private and public support services, again 
depending upon the type and stage of the internationalisation process. Third, while support services and networking activity are a positive combination, this expresses itself differently depending on whether SMEs are traditional or INVs. Finally, we consider that how SMEs use support services regarding their specific internationalisation processes is of vital importance as it adds a complementary perspective to the debate regarding the use of these services.

To explore these issues first, we introduce our theoretical framework before presenting the qualitative methodology and the results. Finally, we develop our main theoretical propositions and conclude with some implications and avenues for further research.

\section{Literature review}

International business and management studies frequently investigate the internationalisation of SMEs (Dominguez and Mayrhofer, 2017; Johanson and Vahlne, 2009; Vahlne and Johanson, 2013), a complicated process that demands significant resources particularly if the goal is to reach distant markets (Ojala, 2009; Zhang et al., 2016). The question of the use of export promotion programmes throughout the SME internationalisation process is therefore, of prime importance.

\section{SME internationalisation processes}

Regarding the internationalisation of firms, there are two dominant research streams: the traditional stage-based approach (Johanson and Vahlne, 2009; Johanson and Wiedersheim-Paul, 1975), in which each 'enterprise gradually increases its international involvement' (Johanson and Vahlne, 1990: 11) and the INV stream that considers INVs as a new type of international SME which expand abroad within six years of their creation (Meschi et al., 2017; Zahra et al., 2000). Although the two streams have partly different views, both schools recognise time as a key concept affecting internationalisation. However, the literature suffers from a lack of conceptual and measurement clarity (Chetty et al., 2014; Hilmersson et al., 2017): the extant literature often uses different measures for the same concept or vice versa. Thus, as pointed out by Hilmersson et al. (2017), time may take different forms: time to internationalisation, point in time and speed of international expansion. These dimensions can allow us to better characterise both processes.

Time to internationalisation is defined as 'the time that has elapsed from a firm's inception to its first sales abroad' (Hilmersson et al., 2017: 28). Extant research shows that the time taken by some firms to internationalisation is short as with INVs undergoing a rapid internationalisation process (Knight and Cavusgil, 2004). They appear 'scantly affected by the negative impacts of distance or uncertainty and do not hesitate to target distant countries from inception' (Dominguez and Mayrhofer, 2017: 1053; see also Vaccarini et al., 2017). By contrast, traditional SMEs take longer to internationalise and gradually increase their international involvement (Johanson and Vahlne, 1990: 11) from close to more distant markets.

Speed of international expansion. SME internationalisation speed is a concept with many dimensions (Casillas and Acedo, 2013). One is the speed of international expansion usually defined as the ratio between the number of export markets for the firm and the time taken to reach this level (Hilmersson and Johanson, 2016). The perception of variations in culture, language, business practice, policies and regulations might hinder SMEs and are often responsible for a low speed of expansion. To explain this, the Uppsala school suggests the concept of psychological distance (Johanson and Vahlne, 1990; Ojala, 2009), created by 'factors preventing or disturbing the flows of information between firm and market' (Johanson and Wiedersheim-Paul, 1975: 308). Specifically, SMEs tend to enter culturally and geographically close countries: first, as they accumulate 
experience, they move to culturally and geographically more distant countries (Avloniti and Filippaios, 2014). Pauluzzo and Shen (2018) observe this process when European SMEs enter Asia: they initially export to culturally similar markets in Europe and only move to Asian markets after gathering experience. Conversely, in INVs, positive managerial perceptions appear to reduce the distance. However, the notion of speed is under scrutiny as evidence indicates that 'a high speed of internationalisation is not only possible for young start-ups; older firms which have been able to develop their capabilities over a longer period of time, seem to be able to exploit these capabilities internationally' (Hilmersson et al., 2017: 28). Moreover, Hilmersson et al. (2017) show that 'in recent years, the time to internationalisation is a more important predictor of internationalisation speed than it was in the past' (p. 28). Thus, we retain time to internationalisation rather than speed to discriminate between the two SME processes of internationalisation.

Point in time of start of internationalisation is defined as the point at which the firm's internationalisation process started. In contemporary markets, trade barriers have been reduced and national legislation tends towards harmonisation; thus, differences between the domestic market and foreign markets have decreased. As a consequence, the point in time when the firm's internationalisation commences (i.e. period of entry) is crucial because it 'is likely to influence the subsequent process' (Hilmersson et al., 2017: 14). Hence, its importance in studies such as ours dealing with temporal aspects of internationalisation.

The needs of SMEs at different stages of their internationalisation process. To enter distant markets, INVs mobilise critical capabilities, such as networking or adaptive production capability. However, they also need to adjust their resources over time and develop new business networks alongside existing ones (Kazlauskaite et al., 2015; Ojala, 2009). With regard to SMEs, experiential learning and commitment building can drive the internationalisation process (Johanson and Vahlne, 2009; Vahlne and Johanson, 2013); these come to resemble continuous interactions across one or more relationships creating opportunities. For Castellaci (2014) and Tian et al. (2018), networks are particularly important when deciding whether or not to enter a new market. Ibeh and Kasem (2011) show that social networks have more influence in the initial phase of internationalisation and business networks are more important during later stages. In light of these factors, SME needs in terms of resources, including networks, might vary according to the stages of the internationalisation processes. Here, in accordance with Efrat and Shoham (2012), we consider two main stages, the early stage (entrance) and the later stage (intensification).

The combinations of time to internationalisation, stages and point in time establish strong theoretical foundations for explaining variety in SME internationalisation processes. However, despite the abundant literature, investigations of the role of support services are rare (Catanzaro et al., 2015; Kazlauskaite et al., 2015), particularly for distant countries. For example, a few studies cite the performance of export promotion services (Freixanet, 2012) and perceptions of their usefulness (Lederman et al., 2010), but there appears to be little research investigating how agents and organisations can help SMEs throughout their internationalisation process.

\section{Internationalisation support services}

Support services are defined as specialised organisations or actors that help firms to attain international expansion by providing advice, contacts, training or support. Scholars usually refer to export support (De Holanda Schmidt and Ferreira Da Silva, 2012; Freixanet, 2012) and not international support at the expense of other modes of entry. That is why, in order to encompass the variety of services in the internationalisation process, we refer to internationalisation support services. 
Support services providers. These services may be organised by the State or private actors; their focus moves beyond export services to include the overall internationalisation processes. When organised by the State, through export promotion agencies or chambers of commerce, these public services are described as export promotion programmes. Activities range from market intelligence, technical assistance participation in trade fairs or financial assistance and subsidies; within France they are large organisations, with funding and services for SMEs provided on a commercial or gratis basis. Some nations make considerable investments in such agencies creating an extensive network of actors enacting national policies (for the situation in France, see Appendix 2). Private support services focus on similar activities, except subsidisation, but they may help firms obtain funding from the State; they also assist entrepreneurs to make international business trips and are usually multipurpose. Private support services are relatively new compared to public ones (Appendix 2).

Both public and private services target all types of firms from SMEs to multinationals. Private companies have gradually emerged as important support service actors, though extant research mostly ignores their role. In his literature review on export promotion programmes, Freixanet (2012) acknowledges their existence but suggests that the majority of studies focus on public actors and governmental initiatives.

Type and variety of internationalisation support services. The internationalisation support services literature distinguishes a number of forms of support (see Table 1) largely related to the study of government export assistance support services rather than private services. Seringhaus and Rosson (1991) identified informational programmes (market studies, conferences, etc.), motivational programmes (building awareness of export opportunities, etc.) and operational programmes (trade shows, trade missions, etc.). Singer and Czinkota (1994) simplified this and used the following commonly utilised distinction: whether they provide informational knowledge (e.g. publications, seminars, workshops, lists of agents and distributors) or experiential knowledge (e.g. introductions to foreign buyers, agent or distributors, trade shows, trade missions and export funding). Going one step further, Czinkota (2002) proposes three complementary forms of export support: (1) transfers of informational and experiential knowledge to increase firm competence (e.g. seminars, consulting and exhibitions abroad), (2) direct or indirect subsidisation of export activities and (3) reduced red tape and legal constraints.

Type of support services users. To study which firms use these programmes, firm characteristics are usually explored. Three variables that dominate are: workforce size, export volume or turnover abroad and international experience/presence. Specific actors are observed such as 'born globals' by Catanzaro et al., 2015) or novel typologies are created such as that by Freixanet (2012); different categorisations have been developed to describe the export development stages of firms with differing segmentation. Freixanet (2012) considers four elements of segmentation: level of internationalisation involvement and skills using criteria such as export volume, size of the export department, creation of permanent establishments abroad and creation of production subsidiaries. Yet, some patterns appear to be similar: non-exporters, those that examine exporting, firms that start exporting, firms that actively export and multinationals.

Use of support programmes. On a general basis, studies observe the use of support services in terms of frequency (Ayob and Freixanet, 2014). The use of internationalisation support services has always been treated in relation to the measure of efficiency, effectiveness or satisfaction of export promotion programmes. Although the use of support services is not the primary objective of these studies, lenses adopted do reveal this element; Table 1 summarises these lenses. 
Table I. Literature on internationalisation support services.

\begin{tabular}{|c|c|c|}
\hline upport & es & \\
\hline $\begin{array}{l}\text { ablic support services } \\
\text { overnmental bodies) } \\
\text { - Extensively } \\
\text { considered } \\
\text {-ivate support services } \\
\text { - Very few studies } \\
\text { explore these } \\
\text { options: banks } \\
\text { (Bartoli et al., } \\
\text { 20I4; Kotabe and } \\
\text { Czinkota, 1992) or } \\
\text { private consulting } \\
\text { firms (Naidu and } \\
\text { Rao, 1993) }\end{array}$ & 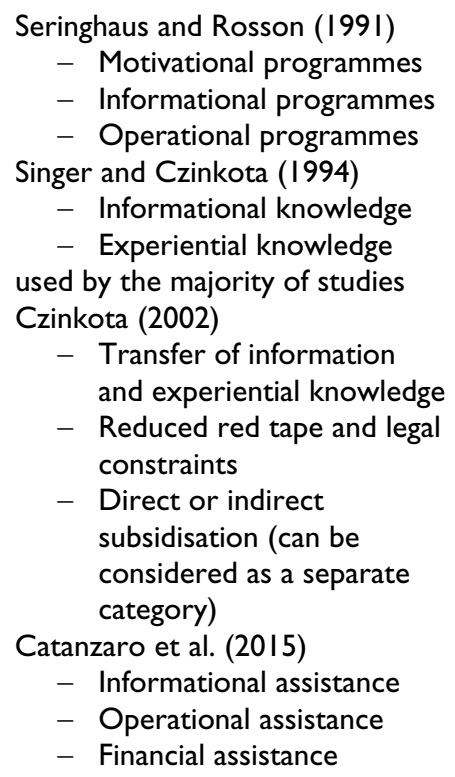 & $\begin{array}{l}\text { following criteria: } \\
\text { - Workforce size } \\
\text { - Export volume or turnover } \\
\text { abroad } \\
\text { - International experience/ } \\
\text { presence (structures abroad) } \\
\text { (some add other criteria such as } \\
\text { industry type, for instance) }\end{array}$ \\
\hline \multicolumn{3}{|l|}{ Use of support services } \\
\hline \multicolumn{3}{|c|}{$\begin{array}{l}\text { - Stage of internationalisation and type of support services } \\
\text { - largest exporters or firms with a more advanced internationalisation stage use more services than } \\
\text { other firms (Ahmed et al., 2002; Francis and Collins-Dodd, 2004; Kedia and Chhokar, 1986; Koksal, } \\
\text { 2009; Naidu and Rao, 1993; Walter, 1983) } \\
\text { - firms have different needs depending on their internationalisation stage; these needs change } \\
\text { depending on the internationalisation stage (Diamantopoulos et al., 1993; Kotabe and Czinkota, } \\
\text { 1992; Naidu and Rao, 1993; Spence, 2003) } \\
\text { - Type of support services } \\
\text { - Export financing is crucial for early stage export firms (Kotabe and Czinkota, 1992; Wiedersheim-Paul, } \\
\text { 1979) }\end{array}$} \\
\hline
\end{tabular}

Few studies focus on the effect of the stage of internationalisation on the use of support services; rather, they focus on whether the firm does actually export. Yet, a consensus seems to have been reached; not surprisingly, large exporters or firms at a more advanced stage of internationalisation use more services.

Crick (1997) and Koksal (2009) combine these aspects to argue that larger, more experienced firms are more familiar with the various support services available from public authorities and so, are better able to exploit their support and identify appropriate assistance for their needs. In addition, Naidu and Rao (1993), Diamantopoulos et al. (1993) and Spence (2003) show that firms have different support needs depending upon their internationalisation stage. However, there are conflicting results. Crick and Chaudhry (2000) suggest a poor frequency of use for support services during the early stage of internationalisation (with the minor exception of trade fairs and market information inquiries), with a minor rise in frequency as firms make greater export commitments. However, Denis and Depelteau (1985) and Seringhaus (1987) indicate that for the most internationally experienced companies, export services mostly support their pre-export activities. This 
result seems to be partially validated by Czinkota (1996), who argues that firms have a greater need of export training services in their early export phase, but more support for sales logistics when they gain experience and reach a more advanced export level.

Regarding the type of support services used, Naidu and Rao (1993) argue that regular exporters are more likely to use private consulting firms and banks than sporadic exporters. Welch and Wiedersheim-Paul (1979) showed that financial help is required in the initial stages of the exporting process, as Kotabe and Czinkota (1992) show that the availability of export financing is crucial for SMEs in the early stages of their involvement. On a more general level, Kedia and Chhokar (1986) mention the importance of the use of banking support services (made through State Promotion Export services) rather that general export advice, for instance.

Other scattered conclusions regarding the use of support services can be found within studies dedicated to their efficiency. These relate to the support services providers themselves; Costa et al. (2017) explain that most industrial business associations provide continuous support for the international operations of SMEs beyond the initial stages. Furthermore, when gathering information on internationalisation, Leonidou et al. (2010) observed that companies relied more on their personal networks than on institutional networks. Finally, when studied by firm size, Buckley (1983) and Sbrana and Tangheroni (1991) show that SMEs are less likely to use support services than larger firms. Finally, Catanzaro et al. (2015) offer some conceptual insights, but focus on the effectiveness of international assistance programmes at specific stages of gradual internationalisation processes.

This literature review draws on the SME internationalisation process and the use of internationalisation support services, revealing three key results that helped build our research design. First, research predominantly focuses on the role of governmental export programmes. We still lack clear distinctions between the types of support provided and the role of private support services and when firms use these different support providers. Second, most studies centre specifically on the decision to start exporting. When studies expand to include support services applied to different stages, the results are unclear. With the notable exception of Freixanet (2012), descriptions of the internationalisation process tend to be limited to the pre-export and export stages but even his classification does not address how each stage of the process aligns with support service use, despite evidence that SME needs shift with their growth and progress. Thus, we will define the use of support services by SMEs more precisely and according to their time to internationalisation and their stage of internationalisation; this requires consideration from the point of inception. Finally, as SMEs and INVs seems to have specific needs related to their size, we seek a better understanding of how they use support during their internationalisation process.

\section{Methodology}

\section{Research context}

The empirical study is based on SMEs in the AURA region in France; it has several notable features. AURA is the second largest French region and the fourth largest region in Europe in terms of gross domestic product. It has a solid industrial base, composed mainly of SMEs (Chamber of Commerce and Industry, 2017). Moreover, regional SMEs are more productive and oriented towards foreign markets than the majority of French SMEs (Bonnet and Lavergne, 2015). This region accounted for $12.9 \%$ of French exports in 2017 and is the first region in terms of industry representing 11\% of French exports towards Asia (Chamber of Commerce and Industry, 2017).

AURA is also a cross-border region with Switzerland; thus, Franco-Swiss cooperation is prioritised across four main business sectors (mecatronic, healthcare, clean tech and outdoor), in an effort to make them more competitive internationally particularly in distant markets. Accordingly, 
the French context offers relevant insights regarding the distinct roles of public and private services for internationalisation efforts as these services have grown steadily in France in recent years. In terms of public support services, there are historically, little regional specificity in the development of support programmes for local SMEs. However, these specificities have slowly disappeared in an effort to simplify public support programmes with the creation, in 2019, of a team (Team France Export) whose action is decentralised through regional agencies. In contrast, private actors do not operate at the regional level and support all SMEs.

\section{Research design}

Theorising. The exploratory research design relies on a multiple case study. We apply this qualitative method for the richness of data and material it provides, which can produce novel theoretical insights (Cuervo-Cazurra et al., 2016). In particular, a multiple case study provides the depth necessary to understand the complex process of SME internationalisation and how it evolves over time (Eisenhardt, 1989), with a special emphasis on the role of support services throughout the process. In line with Eisenhardt and Graebner (2007), we adopt a positivistic case study approach considering that inductive theory building from cases constitutes a means to an end, producing testable propositions and new theories to then be deductively tested thus, 'completing the cycle' (p. 25).

Case selection. Both Eisenhardt (1989) and Yin (2009) recommend multiple case studies, for providing analytical generalisation. We did not target quantification as our case selection is theoretically not statistically oriented (Piekkari et al., 2009). In order to have a homogeneous unity of analysis, we selected SMEs that varied along theoretically relevant dimensions (Eisenhardt, 1989; Miles and Huberman, 1994). We retained 32 SMEs with 20-249 employees operating in four business sectors that authorities prioritise in the AURA region. These SMEs have all entered Asia gradually or rapidly, with or without the support of publicly available services. We also considered the point in time when internationalisation commenced (Hilmersson et al., 2017), distinguishing between three time periods of SME internationalisation in Asia for the comparison to be undertaken (before 2001, between 2001 and 2010, and after 2010). ${ }^{3}$ For example, Table 3 shows that in period 1 (entry into Asia before 2001), we had five traditional SMEs and four INVs thus, respecting Eisenhardt's recommendations. This multi-focal forced us to have a large- $\mathrm{N}$ case study to increase the robustness of the findings and support cross-case replications.

Data sources. The qualitative study, conducted from March 2016 to January 2017, solicited responses from the 32 SME managers (Appendix 1), using semi-directive interview guides and a chronological timeline. The interview guide includes four themes: (1) respondent career path and international experience, (2) the SME's internationalisation process and antecedents of the decision to enter Asia, (3) the internationalisation process in Asian markets and (4) the role of support services in this internationalisation process. All interviews were recorded ( 35 hours) and fully transcribed ( 355 pages). The data analysis relied on qualitative content analysis available with Atlas.ti software. This software was used for three reasons: first, the possibility to visualise, annotate, easily analyse discourse and group data by different variables (date of creation, revenue, first country reached in Asia, for example). Second, the software was necessary to work as a team (for double coding, adding analysis though memo, etc.). Third, it allowed us to build chronological 'path' for each SME and each group of SMEs. We used systematic double coding, reflecting a broad set of literature-derived codes. Specifically, we obtained 106 codes, sorted into 20 categories (refined from 286 codes initially). The process of code refinement reflected common procedures for whole-text qualitative content analysis (Ryan and Bernard, 2000). Moreover, the data analysis classified the focal SMEs according to three criteria: their time to 
internationalisation (gradual vs rapid), their internationalisation stage (entry, indicating that the SME has just made its first sales in an Asian country, or intensification, reflecting entry into another Asian market or significant increases of sales in Asia; these stages were relevant based on the interviews) and the point in time they enter into Asia, according to three periods (before 2001, between 2001 and 2010, and after 2010). Based on these periods, we built Table 2 from each SME's use of support services during their internationalisation in Asia by triangulating secondary data and interviews. In line with our positivistic approach, we combined a variety of primary and secondary data, well-adapted to large- $\mathrm{N}$ case studies (Yin, 2009). For example, 20 support services actors - public and private - were also interviewed to better characterise their offer and use. To obtain secondary data, we attended conferences and seminars dedicated to SME internationalisation and reviewed specialised journals and publications by regional institutions (chamber of trade and industry, poles of competitiveness, see Appendix 3). Finally, our preliminary and final results were presented in January 2017 at the OSCI (a representative organisation of private support actors, often small companies) Annual meeting and in January 2019 to the (regional) Team France; the feedback obtained also supported the triangulation of our data.

We are particularly interested here in the difference between the use of support services according to the time to internationalisation, the stage and the point in time when internationalisation starts: the multiple uses and the non-use are particularly significant. Table 3 aims to show three tendencies: the different use of public and private support services by SMEs entering into Asia by period, the differences between SMEs with a gradual internationalisation process (traditional SMEs) and those with a rapid one (INVs), and finally the differences between their stage of internationalisation (entry or intensification). Please note that Table 3, based on the quantitative use of support services by SMEs, is a support for our analysis. It does not provide qualitative specificities such as the perception of services, disappointment and so on. Details on the use of support services by SME are listed in Appendix 1, and the support services used are detailed in Appendix 2.

\section{Findings}

Of the 32 French SMEs studied, considering the time to internationalisation, 19 are traditional SMEs exhibiting gradual internationalisation processes. The majority of these firms began their internationalisation in closer markets, usually Europe, though one traditional SME started internationalising 17 years after its creation in both Asia and Europe, after having developed its product in France. When considering the point in time of start of internationalisation, we observe that the decision of traditional SMEs to enter Asian markets follows a reactive approach, especially for SMEs that entered before 2010. Pioneering SMEs (before 2001) went to Asia to accompany a customer or strategic partner, while SMEs in the following period (between 2001 and 2010) seek new areas for growth in response to the slowdown of European markets. In the more recent period (after 2010), traditional SMEs tend to make better use of the opportunities Asian markets offer on a somewhat opportunistic basis and not without risks.

The 13 SMEs that experienced rapid internationalisation exhibit the characteristics of INVs (Zahra et al., 2000). Six of them entered Asia within six years of their creation, without any prior international experience; seven began by internationalising in Europe but rapidly entered Asia in the years thereafter. Compared with traditional SMEs, the decision of INVs to enter Asian markets is the result of a more exploratory or adventurous approach. Regarding the point in time of the start of internationalisation, this is particularly the case for INVs that penetrated this 'new playground' before 2010. After 2010, the approach appears more rational and coordinated; Asia is considered as a market among others.

For both traditional SMEs and INVs, we observe an accelerated intensification of their presence in Asia over time (Table 2). We identify 12 configurations that correspond to the uses of support services by SMEs according to the time to internationalisation (gradual vs rapid), the stage of the process (entry 


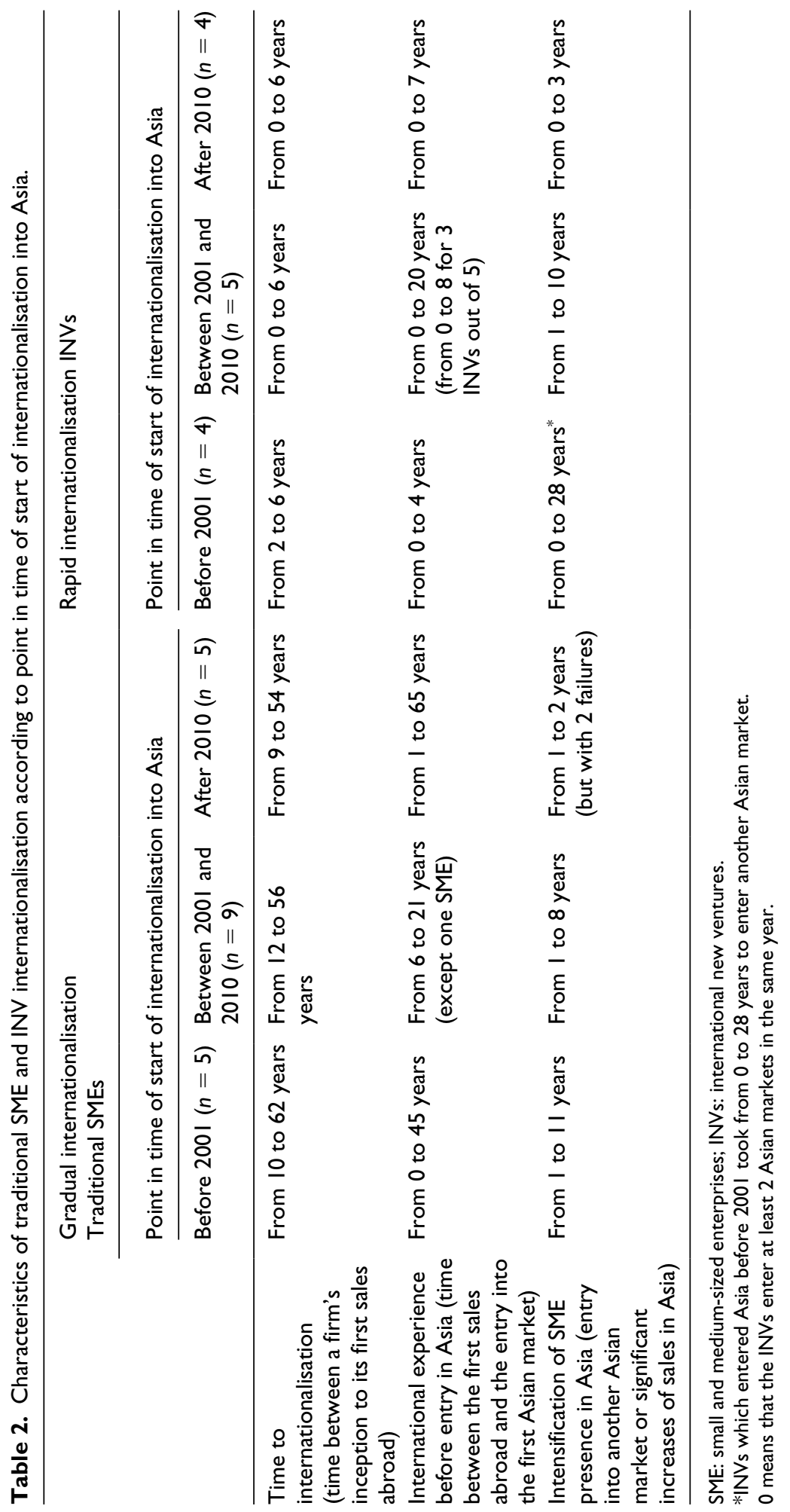




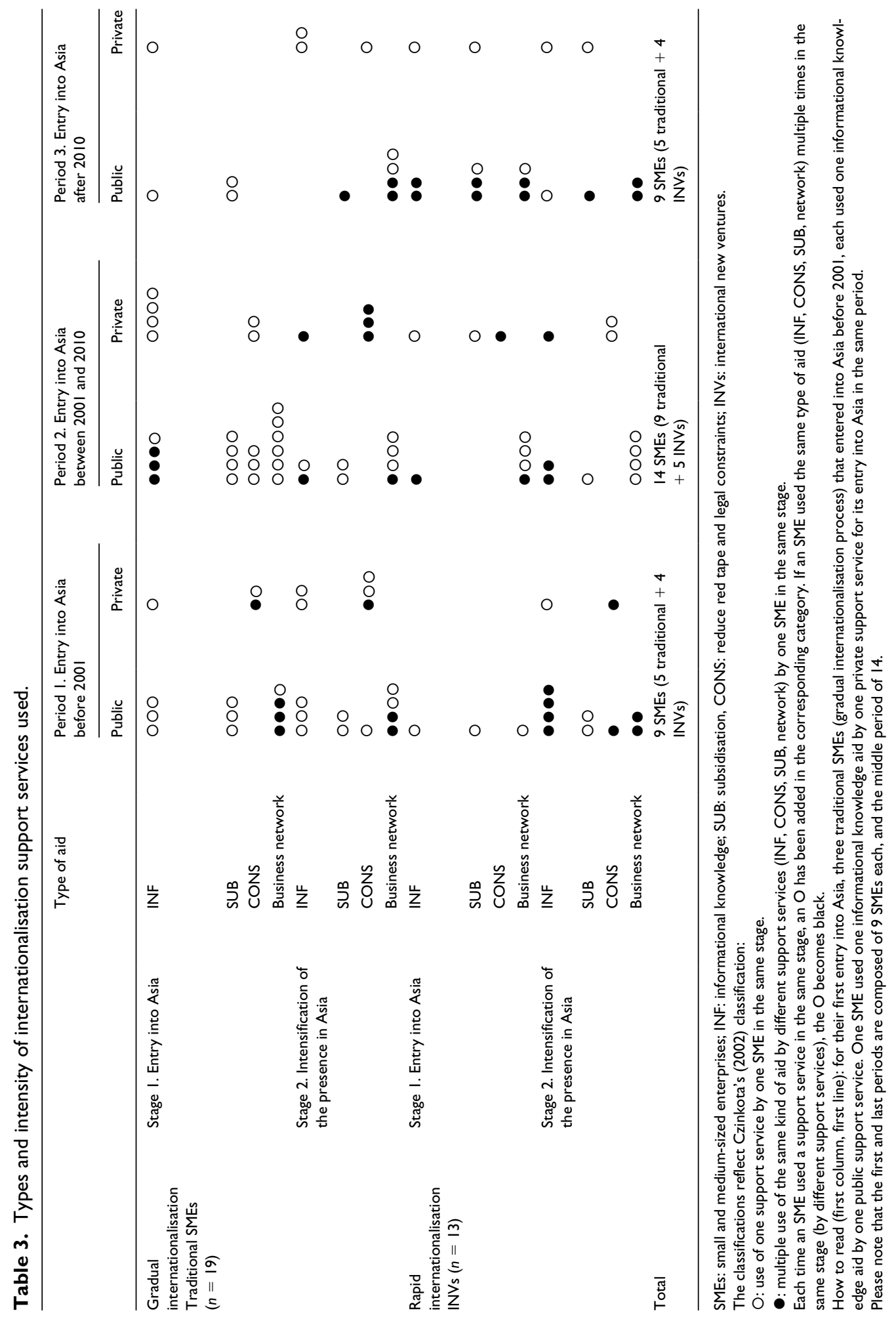


vs intensification) and the point in time of start of internationalisation into Asia (before 2001, between 2001 and 2010, and after 2010). Table 3 provides a synthesis of the results. Considering the uses of support services by traditional SMEs and INVs, four results area afforded particular attention.

First, the point in time of start of internationalisation (time period) matters. Offers of support from dedicated services increased substantially over time and became more complex (Appendix 2). Prior to 2001, SMEs had fewer choices, private provision grew rapidly after 2001 and became more visible with the creation of OSCI. During the period under study, development in Asia also engendered different possibilities for SME expansion. Countries with previously protectionist economic policies opened, and this created new opportunities that in turn demanded new information, legal and funding competencies. However, as supply has increased, the use of support services over time has not increased in tandem. The frequency of use is not proportional to the increased supply over the three periods. The complexity of the offer and the growing number of actors might explain why most SMEs tend to choose the same sources. As one of our respondents pointed out,

There is a lack of clarity in those support services, public and private. They are not well structured for now in France. (SA9)

In total, the 32 SMEs we study relied on more than 30 distinct public and private actors for support for their internationalisation in Asia; however, we note a strong concentration around five types of public actors - Chambers of Commerce and Industry (20/32), Coface (19), BPI France/OSEO (16), ERAI (15) and Business France (14) - and three types of private entities that specialise in internationalisation (15), banks (13) and business law firms (9). On average, each SME called upon six sources of support before and during its internationalisation process.

Second, within each period, the use of support services differs according to the time to internationalisation. Generally, traditional SMEs with gradual internationalisation processes rely more on support services than INVs during their internationalisation. In particular, traditional SMEs, from the start, mobilise public and private support services to understand distant markets; they usually know what they need and which actors to contact. Public support services are used to meet specific needs, such as targeted prospecting (specialised fairs) or recruitment (volunteering for international experience). Private support services are also used to address legal and administrative constraints, particularly if they choose to create a local entity.

We have as a partner an international law firm that accompanies us on legal issues such as brand protection, creation of an internet domain, etc. (OT1)

By contrast, INVs chose to access Asian markets with limited help.

We were approached by Chambers of Commerce and Industry and by Business France, but this represents a cost. I considered that we cannot pay. So we went to Asia alone. (SA3)

Their entry stage is characterised by openness and curiosity, usually followed by a long phase of stagnation. Whatever the period observed, the trend remains the same: traditional SMEs mobilise more support services than INVs. Although over the last period (after 2010) the gap in the use of support services between traditional SMEs and INVs seems to be narrowing.

Third, the two types of SMEs use different support services according to their stage of internationalisation. In a general sense, the use of support services is more important during the entrance phase than the intensification phase for traditional SMEs. The opposite holds for INVs that make a greater use of support services during the intensification stage of internationalisation. Traditional SMEs test the usefulness of public support services during their entry phase; they then appear to conclude that they might be too general and inefficient to offer appropriate contacts, as well as too 
time-consuming due to administrative burdens. Experience with public actors appears insufficient, though they may use private support services for legal assistance and to support expanding business networks. Therefore, traditional SMEs are willing to pay more for private support services they regard as faster, customised to their needs and more efficient.

We were quite disappointed with Business France's response. That's why we chose to work with private support services. They have an international network and fully understand our problems. It costs more but we go faster! (MECA2)

By contrast, INVs use public support services more intensively than do traditional SMEs. During the subsequent intensification phase though, these INVs used cheaper or free services to prospect (mainly public) and gain financial aid (only public):

Business France offered us the opportunity to participate in an international exhibition at lower costs. It was interesting, concrete and well-organized: we just needed to meet them, they took care of everything at a very affordable price, and we benefited from the reputation of the French pavilion. (MECA1)

Here again, we observe the same trend whatever the period that traditional SMEs use more support services during the entrance phase and INVs use more support services during the intensification phase with a gap that tends to subside over period three (after 2010). Table 4 provides SME verbatim for each period and type of support service.

Fourth, we observe recurrent uses of networks to support the internationalisation of SMEs in Asia but in a different way. For traditional SMEs, these networks are usually mobilised as a prerequisite to other forms of support. Beyond the use of public and private support services, traditional SMEs use their existing business networks as the best means to penetrate Asian markets. They claim to have the necessary internal or external resources to assume responsibility for their own development, though the processes are not without failures and significant switching costs.

Without your own network, there is little possibility that you enter new markets, especially Asian ones. Yesterday, I was talking with a counterpart about Korea. We exchanged views, experiences and lessons learned on this market. (MECA7)

By contrast, INVs seem to make better use of networks as complements to public support services. Public support services are relied upon for informational and experiential knowledge while networks are used to mobilise the resources and skills needed. The mobilisation of public actors who are inexpensive or free is largely due to the youth of these INVs, with limited financial resources:

Since we are a young SME, time is precious and one Euro is one Euro. We seek to optimize the search for information in order to identify who is best placed to support us. The challenge is to choose the right partners, those who can have an impact. (OT3)

They are resourceful and seek tips to learn and gather information at lower costs. Then during intensification phases, some public support services provide a little funding, but networks facilitate market penetration, functioning as business makers.

\section{Discussion}

The use of support services by French SMEs in their internationalisation into Asia varies according to two main criteria (Table 3): the time to internationalisation and the stage of this process. These variations are observed in relation to the point in time of start of internationalisation (the three 


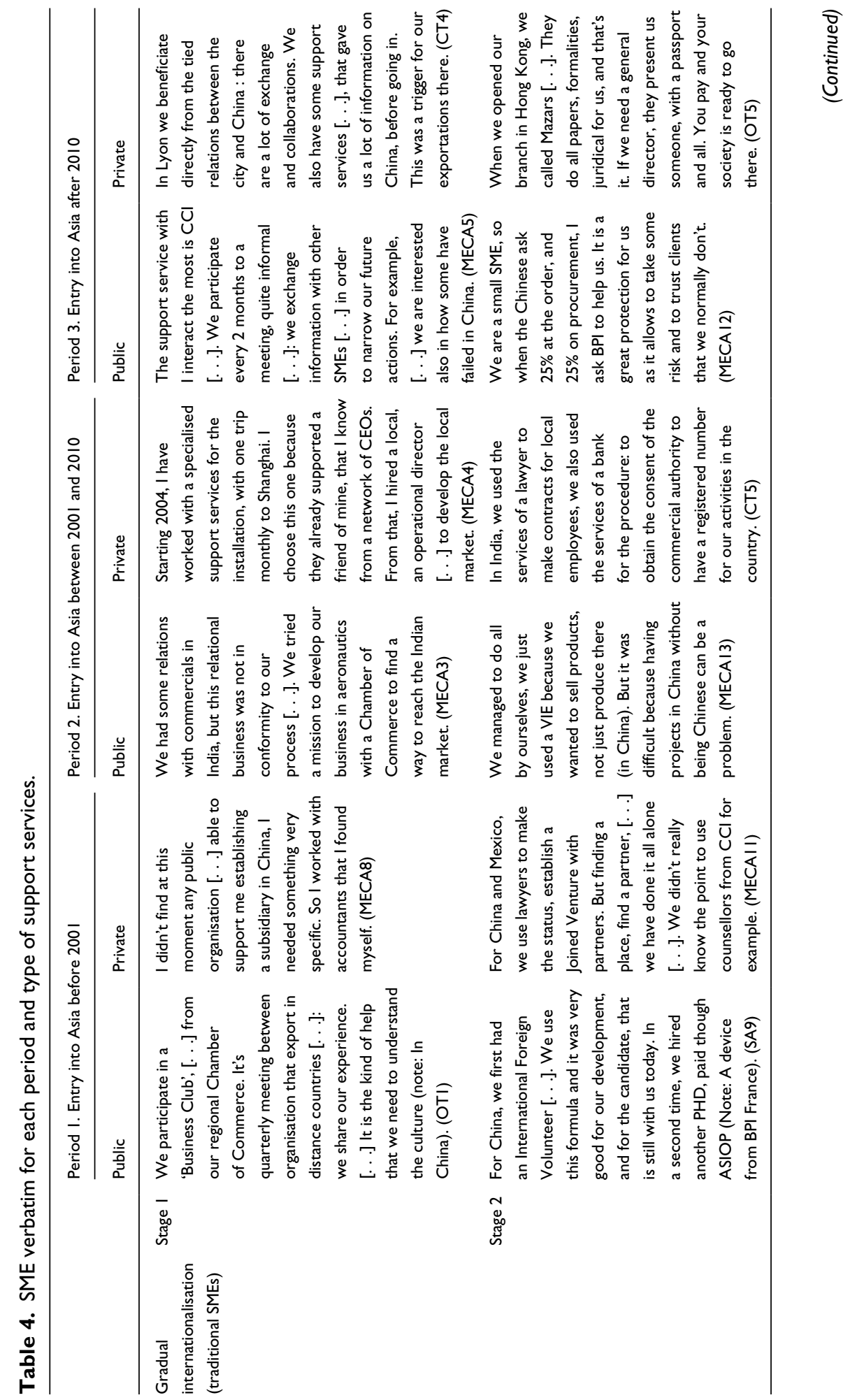




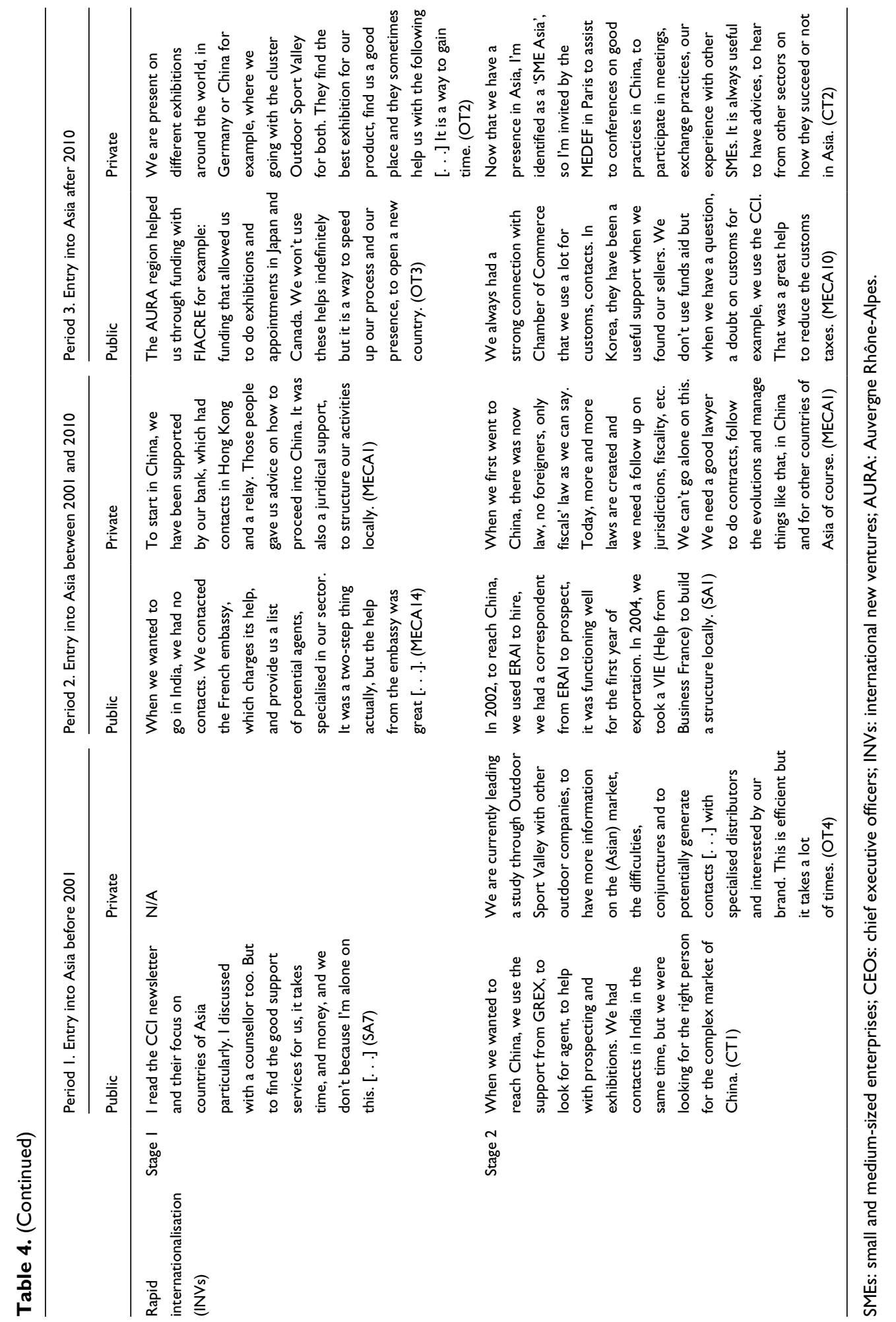


periods). We find that over the last period (after 2010) the gap in the use of support services between traditional SMEs and INVs seems to be narrowing, suggesting a moderating effect of point in time on the subsequent use of support services. Our results contribute to those of Hilmersson et al. (2017) regarding the 'moderating effect on the time passed since the start of internationalisation on the relationship between time to internationalisation and speed' (p. 25). By identifying 12 different configurations, this study provides a greater understanding of the use of internationalisation support services and challenges conventional ways of studying export services designed to support SMEs.

\section{Type of support services and time to internationalisation}

In his seminal work, Freixanet (2012) called for longitudinal analyses that could confirm the causal effects of export programmes. Acting upon this suggestion, we have analysed the decision to use (or not) internationalisation assistance support during the entire internationalisation process, not solely at a specific moment. We thus affirm Freixanet's (2012) finding that the use of various export programmes varies with the type of assistance and international experience of the company. We also go one step further by showing that the use of support services, both in terms of type, whether public or private, and intensity, results from the influence of the time to internationalisation (gradual or rapid).

In particular, our results show that support services help traditional SMEs to build knowledge, extend networks, reduce psychic distance (Johanson and Vahlne, 1990; Ojala, 2009) with Asia and therefore, support gradual international involvement (Johanson and Vahlne, 1990). This contrasts with INVs that use fewer support services given their lack of resources. Traditional SMEs also look for specific private support services and are ready to pay more than INVs and rely less on funding - a specificity of public support services. We also observe high levels of disappointment from traditional SMEs regarding public support services while INVs found some value in those services.

This study also constitutes an attempt to resolve some conflicting results in the literature. Ahmed et al. (2002), Crick (1997) and Kedia and Chhokar (1986) argue that most experienced companies are more likely to use international support structures. Our findings indicate, contrary to Crick (1997), that the use of internationalisation assistance services declines as the firm gains experience abroad if it is a traditional SME, but the same finding does apply to INVs.

In the light of our results, we propose that

The use of support services by SMEs varies according to the time to internationalisation, such that traditional SMEs use support services more intensively than INVs, particularly private ones. (P1)

\section{Type of support services and stage of internationalisation}

Our second proposition is to separate the different stages of the SME internationalisation process to study the use of support services. Previous literature had partially identified that the export phase (early export phase to more advanced) could impact the use of support services. Czinkota (1996) and Crick (1997) showed that firms have a greater need of export training services in their early export phase and that the type of support may vary. Again, we go one step further and complement Czinkota (1996) and Crick's (1997) results showing that SMEs have a greater need for export training services in their early export phase but only if they are in a gradual process of internationalisation. In contrast, most INVs realise they need help after their first steps at the local level.

Three main arguments can be put forward to reflect these differentiated uses by traditional SMEs versus INVs. First, INVs are not aware of the variety and the complexity of public and private support services and what they offer to SMEs, which seems to complement the findings of Koksal (2009), who shows that more experienced companies are more familiar with the support services available from public authorities, and so better understand and rely on the assistance options that suit their needs. 
Second, through their experience, their business network, INVs learn to use support services to reinforce a local presence; they look for easy access and cheap services, essentially because of their size and desire to enter into multiple markets simultaneously (Dominguez and Mayrhofer, 2017). Consequently, they do not have many resources dedicated to each market. This differs from traditional SMEs that seem to be more cautious and reduce their uncertainty of distant markets by consulting multiple support services from the early stages of the process. Third, it has been argued that some perception of barriers to internationalisation (Leonidou et al., 2010) differ significantly according to the type of SME (Uner et al., 2013). Traditional SMEs develop less risky strategies than INVs to enter foreign markets (Chetty and Campbell-Hunt, 2004); support services can play a crucial role in removing internal barriers, especially informational ones that arise from the home country. Once they have entered and with the experience acquired on these markets, traditional SMEs will develop their own resources to gradually assume internationalisation. In contrast, INVs perceive procedural barriers as the major obstacle. These external barriers emerge once they reach foreign markets and are more difficult to control than those from the home country (Leonidou, 2004). At this stage, support services provide key additional resources to reduce the effects of these barriers and help INVs to intensify their presence.

Furthermore, as the use of internationalisation assistance services varies with experience, the content of this support also differs (Table 3). Singer and Czinkota (1994) hypothesise that services providing objective knowledge (e.g. workshops, advice) are more useful during pre-export activities, whereas experiential knowledge services (e.g. trade shows abroad) are more useful at advanced stages. We do not find such a clear distinction; rather, the use of these services varies with the time to internationalise and stage of internationalisation. For example, objective knowledge support appears more important for traditional SMEs that enter Asia, as well as when INVs intensify their presence. Experiential knowledge remains more important for traditional SMEs than for INVs overall. The findings also reveal distinct, but complementary, uses of private and public support services. Consistent with Zahra and George (2002), our results show that INVs seek tips and free services, given the scarcity of financial and human resources, but only during the intensification stage. The use of private support actors is less important during this stage, unless traditional SMEs seek them after being disappointed by public services. Moreover, SMEs use private services to supplement public services and their network. Among the services offered, only private actors provide legal advice (public actors are never solicited for this service). Because traditional SMEs know what services are available, they pursue an optimal mix of private and public services and business networks. Although the number of private actors has grown in the past 20 years, three types dominate: private office settings that specialise in internationalisation, banks and business lawyers.

We thus propose that:

The use of support services by SMEs varies according to the stage of internationalisation process, such that traditional SMEs use private and public support services more intensively during the entry stage while INVs use public ones more intensively during the intensification stage. (P2)

\section{Support services and networks}

Our third contribution was to reveal the link between networks and the use of support services. Therefore, we distinguish public and private services from other non-professional actors that are part of SME business networks, which have expertise or international experience in Asia and can thus provide assistance to SMEs. Consistent with former research (Kazlauskaite et al., 2015; Prashantham et al., 2018; Vahlne and Johanson, 2013), integrating business networks helps accelerate internationalisation, and this source provides important, informal support at every stage of the internationalisation process, especially during the entry stage if the SME is traditional. We also complement previous 
studies showing that the network and support services are rarely mutually exclusive. The business network acts as a prerequisite for the internationalisation of traditional SMEs and provides clear recommendations for selecting support services. This result agrees with Castellaci (2014), who shows that networks are particularly important in the decision to enter a new market. While our findings support this importance for the entry phase, this is particularly true for traditional SMEs as initially, they rely on their network to gather information and identify the relevant and specific support services that they may need. As shown by Kazlauskaitè et al. (2015), networks influence gradual internationalisation efforts into Asia. For INVs, the business network appears to be more a complement to public support services during the intensification stage. This complements Kazlauskaite et al. (2015) and Ojala (2009) on business networks, showing that INVs develop new business networks alongside existing ones, and that support services help INVs to develop their network.

Consequently, this study advances the business network literature by establishing the differentiated role of business networks in the internationalisation processes of SMEs in relation to support services:

The use of business networks in relation to support services varies according to the SMEs' internationalisation process, such that traditional SMEs use their business networks as a prerequisite before using support services, while INVs use their business network alongside support services. (P3)

\section{Conclusion}

This article explores how services are used during internationalisation to clarify and theorise upon which support services are important to assist SMEs during this process to help them, particularly when focusing upon distant markets, such as Asia. We explicitly address the point in time when the internationalisation begins and its moderating effects on the subsequent use of support services; this has been somewhat overlooked in the extant literature. Based on a multi-case study of French SMEs, summarised in a set of 12 configurations, this research provides three key advances.

First, the temporal aspect of internationalisation which still represents 'an under-researched area' (Hilmersson et al., 2017: 32) can offer an explanation for contradictory results in previous research on use of support services (Yoo et al., 2012). Our results emphasise the impact of the time to internationalisation; they indicate that the use of international support services declines as the firm gains experience if the process is gradual, but the same finding does not hold for a rapid internationalisation process. Second, exploring the stage of internationalisation can complement existing knowledge (Crick, 1997; Czinkota, 1996), we advance this argument when demonstrating that SMEs have a greater need of support services at the entry stage, but only if they pursue a gradual process of internationalisation. On the contrary, INVs, with rapid progress need support after their first local steps during the intensification stage. Third and consistent with previous research (Kazlauskaite et al., 2015; Prashantham et al., 2018), integrating business networks helps accelerate internationalisation; to complement previous studies we also demonstrate that network and support services are rarely mutually exclusive. Reflecting their gradual internationalisation process, traditional SMEs use business networks as a prerequisite before using support services while support services help INVs to develop their network during their rapid internationalisation.

These findings have several managerial implications. In particular, our study can help SMEs clarify and diagnose their needs by acknowledging the impact of the current stage in the internationalisation process on their needs. In turn, they can determine which tailor-made proposals offered by private and public actors are more applicable to their internationalisation efforts. In addition, they could also proactively exploit the complementarity between their business network (that represents a 'parallel support process' ${ }^{4}$ from which they can acquire additional resources and that could help them select support services) and support services that offer different kinds of support. Furthermore, support services, public or private, can use these findings to target their offer 
more precisely according to the different types of SMEs (traditional SMEs vs INVs) they encounter and their stage of internationalisation. We have identified 12 configurations that correspond to SME profiles. Professional service providers can use these to refine their offers by creating tools that could help diagnose SME needs, diversify their competence and diminish their apparent reluctance to use services that do not reflect their precise needs. Support service providers must also be aware of the role played by SME networks so that they can act in a complementary way. For both types of SMEs, networks represent key sources of knowledge during entry for traditional SMEs and intensification phases for INVs. Support services providers should therefore consider them as a parallel, and complementary, service to their own actions and must be able to identify them.

This article also has several limitations that suggest avenues for further research. Methodologically, we focused on a sample of French SMEs in one region. It would be interesting to examine other contexts to uncover any notable differences in the uses of support services. Extensions to other regions or geographic contexts might reveal whether the SME's home country affects its use of support services; we anticipate that the economic, institutional and cultural characteristics of the home country likely influence how public and private support services develop their offers. Other factors of heterogeneity among the SMEs (Ingley et al., 2017), such as industrial settings, could be observed in order to study the use of support services by SMEs for their internationalisation.

Given the limitations of our data, this research did not allow us to consider the speed of internationalisation. A possible extension could be to distinguish between time to internationalisation and speed of internationalisation as recommended by Chetty et al. (2014) in order to refine the two SME internationalisation processes. Additional studies could also address how support services help overcome barriers to internationalisation (Narayanan, 2015) and how SME networks may act as a 'parallel support process' in their internationalisation process. Reflecting Catanzaro et al. (2015), we call for more studies that investigate the impact of support services on SME performance according to whether their internationalisation process is gradual or rapid. Finally, the efficiency of these support services is an important question that has crystallised almost all of the debate. It is often measured regarding the increase of exports but not often regarding the ability of the firm to transition from one stage of internationalisation to another. Furthermore, with the notable exception of CiszewskaMlinaric (2018), who illustrated that some types of support increase export intensity, analyses of efficiency do not sufficiently distinguish between the type of support proposed. We argue that efficiency, in order to be evaluated, needs to consider not only the service in itself, but also the types of firms that use it according to its internationalisation stage (entrance or intensification) and time to internationalisation (gradual or rapid). Further research could draw from these first results and contribute to refining the objective measurement of efficiency of these support services, as well as the satisfaction and effectiveness of such support services using more subjective measures.

\section{Acknowledgements}

We thank the anonymous reviewers of ISBJ that have significantly improved the paper thanks to their insightful and constructive comments.

\section{Funding}

The authors disclosed receipt of the following financial support for the research, authorship, and/or publication of this article: This research is part of a Franco-Swiss project that has received a European grant through the European Regional Development Fund (ERDF). We acknowledge it for its financial support.

\section{ORCID iD}

Nathalie Belhoste (iD https://orcid.org/0000-0002-7250-4705 


\section{Notes}

1. In line with several authors (Dominguez and Mayrhofer, 2017; Kalinic and Forza, 2012; Olejnik and Swoboda, 2012), 'traditional SMEs' is used to designate small and medium-sized enterprises (SMEs) that follow a gradual approach akin to the traditional Uppsala model, regardless of their industry.

2. Some consider that they have a positive impact on the internationalisation performance (Brouthers and Wilkinson, 2006; De Chiara and Minguzzi, 2002; Gençtürk and Kotabe, 2001; Leonidou et al., 2011; Sousa and Bradley, 2009), while others show that their effect remains limited (Francis and Collins-Dodd, 2004; Ramsden and Bennett, 2005).

3. These dates reflect potentially important contextual influences, in that 2001 corresponds to China's entry into the World Trade Organisation and was a strong signal for firms seeking to access Asian markets, and 2010 marks the date of reforms to the rules for French public aid for internationalisation.

4. We thank one of the reviewers for suggesting this idea and expression.

\section{References}

Ahmed Z, Mohamed O, Johnson J, et al. (2002) Export promotion programs of Malaysian firms: International marketing perspective. Journal of Business Research 55(10): 831-843.

Avloniti A and Filippaios F (2014) Unbundling the differences between psychic and cultural distance: An empirical examination of the existing measures. International Business Review 23(3): 660-674.

Ayob AH and Freixanet J (2014) Insights into public export promotion programs in an emerging economy: The case of Malaysian SMEs. Evaluation and Program Planning 46(4): 38-46.

Bartoli F, Ferri G, Murro P, et al. (2014) Bank support and export: Evidence from small Italian firms. Small Business Economics 42: 245-264.

Bonnet M and Lavergne H (2015) Les exportations rhônalpines portées par les entreprises multinationales. Insee Analyses Rhône-Alpes, No. 43. Available at: https://www.insee.fr/fr/statistiques/1302253

Brouthers LE and Wilkinson TJ (2006) Trade promotion and SME export performance. International Business Review 15: 233-252.

Buckley P (1983) Government-industry relations in exporting: Lessons from the United Kingdom. In: Czinkota MR (ed.) Export Promotion, the Public and Private Sector Interaction. New York: Praeger Publishers, pp.51-65.

Casillas JC and Acedo FJ (2013) Speed in the internationalisation process of the firm. International Journal of Management Reviews 15(1): 15-29.

Castellaci F (2014) Service firms heterogeneity, international collaborations and export participation. Journal of Industry, Competition and Trade 14(2): 259-285.

Catanzaro A, Messeghem K and Sammut S (2015) Impacts of export support: A conceptual model for export start-ups. Management International 19(2): 226-245.

Chamber of Commerce and Industry (2017) Key figures of Auvergne Rhone-Alpes in 2017-2018. Available at: https://www.auvergne-rhone-alpes.cci.fr/sites/default/files/fichier_telechargement/economie-2018-ccauvergne-rhone-alpes-an.pdf

Chetty S, Johanson M and Martín OM (2014) Speed of internationalisation: Conceptualization, measurement and validation. Journal of World Business 49(4): 633-650.

Chetty SK and Campbell-Hunt C (2004) A strategic approach to internationalisation: A traditional versus a born-global approach. Journal of International Marketing 12: 57-81.

Ciszewska-Mlinaric M (2018) Export intensity, geographic diversification and the role of public support: The evidence from old and new Europe SMEs. Entrepreneurial Business and Economics Review 6(2): 45-69.

Costa E, Soares AL and De Sousa J (2017) Institutional networks for supporting the internationalisation of SMEs: The case of industrial business associations. Journal of Business \& Industrial Marketing 32(8): $1182-1202$.

Crick D (1997) UK SMEs' awareness, use, and perceptions of selected government export assistance: An investigation into the effect of the internationalisation process. The International Trade Journal 11(1): $135-167$. 
Crick D and Chaudhry S (2000) UK SME's awareness, use, and perceptions of selected government export assistance: An investigation into the effect of ethnicity. International Journal of Entrepreneurial Behaviour and Research 6(2): 72-89.

Cuervo-Cazurra A, Ganitsky J, Luo Y, et al. (2016) Global strategy and emerging markets. AIB Insights 16(4): 3-6.

Czinkota MR (1996) Why national export promotions? International Trade Forum 2: 10-13.

Czinkota MR (2002) Export promotion: A framework for finding opportunity in change. Thunderbird International Business Review 44(3): 315-324.

De Chiara A and Minguzzi A (2002) Success factors in SMEs' internationalisation processes: An Italian investigation. Journal of Small Business Management 40: 144-153.

De Holanda Schmidt F and Ferreira Da Silva JF (2012) Export assistance: A literature review and challenges for future research. Discussion Paper no. 191. Brasilia: Institute for Applied Economic Research. Available at: http://repositorio.ipea.gov.br/bitstream/11058/5141/1/DiscussionPaper_191.pdf

Denis JE and Depelteau D (1985) Market knowledge, diversification, and export expansion. Journal of International Business Studies 16(3): 77-89.

Diamantopoulos A, Schlegelmich B and Tse Y (1993) Understanding the role of export marketing assistance: Empirical evidence and research needs. European Journal of Marketing 27(4): 5-18.

Dominguez N and Mayrhofer U (2017) Internationalisation stages of traditional SMEs: Increasing, decreasing and re-increasing commitment to foreign markets. International Business Review 26(6): 1051-1063.

Efrat K and Shoham A (2012) Born global firms: The differences between their short-and long-term performance drivers. Journal of World Business 47(4): 675-685.

Eisenhardt KM (1989) Building theories from case study research. Academy of Management Review 14(4): $532-550$.

Eisenhardt KM and Graebner ME (2007) Theory building from cases: Opportunities and challenges. Academy of Management Journal 50(1): 25-32.

European Commission (2015) User Guide to the SME Definition. Brussels: Publications Office of the European Union.

Francis J and Collins-Dodd C (2004) Impact of export promotion programs on firm competencies, strategies and performance: The case of Canadian high-tech SMEs. International Marketing Review 4(5): 474-495.

Freixanet J (2012) Export promotion programs: Their impact on companies' internationalisation performance and competitiveness. International Business Review 21(6): 1065-1086.

Gençtürk EF and Kotabe M (2001) The effect of export assistance program usage on export performance: A contingency explanation. Journal of International Marketing 9(2): 51-72.

Hilmersson M and Johanson M (2016) Speed of SME internationalisation and performance. Management International Review 56(1): 67-94.

Hilmersson M, Johanson M, Lundberg H, et al. (2017) Time, temporality, and internationalisation: The relationship among point in time of, time to, and speed of international expansion. Journal of International Marketing 25(1): 22-45.

Ibeh K and Kasem L (2011) The network perspective and the internationalisation of small and medium sized software firms from Syria. Industrial Marketing Management 40(3): 358-357.

Ingley C, Khlif W and Karoui L (2017) SME growth trajectories, transitions and board portfolios: A critical review and integrative model. International Small Business Journal: Researching Entrepreneurship 35(6): 729-750.

Johanson J and Vahlne JE (1990) The mechanism of internationalisation. International Marketing Review 7(4): 11-24.

Johanson J and Vahlne JE (2009) The Uppsala internationalisation process model revisited: From liability of foreignness to liability of outsidership. Journal of International Business Studies 40(9): 1411-1431.

Johanson J and Wiedersheim-Paul F (1975) The internationalisation of the firm - Four Swedish cases. Journal of Management Studies 12(3): 305-322.

Kalinic I and Forza C (2012) Rapid internationalisation of traditional SMEs: Between gradualist models and born globals. International Business Review 21(4): 694-707. 
Kazlauskaitè R, Autio E, Gelbūda M, et al. (2015) The resource-based view and SME internationalisation: An emerging economy perspective. Entrepreneurial Business and Economics Review 3(2): 53-64.

Kedia BL and Chhokar J (1986) Factors inhibiting export performance of firms: An empirical investigation. Management International Review 26(4): 33-43.

Knight GA and Cavusgil ST (2004) Innovation, organisational capabilities, and the born global firm. Journal of International Business Studies 35: 124-141.

Koksal MH (2009) Organisational and exporting determinants affecting export promotion program awareness, utilization, and usefulness level. Journal of Euromarketing 18(4): 219-232.

Kotabe M and Czinkota MR (1992) State government promotion of manufacturing exports: A gap analysis. Journal of International Business Studies 23(4): 637-658.

Lederman D, Olarreaga M and Payton L (2010) Export promotion agencies: Do they work? Journal of International Business Studies 91: 257-265.

Leonidou LC (2004) An analysis of the barriers hindering small business export development. Journal of Small Business Management 42(3): 279-302.

Leonidou LC, Katsikeas CS and Coudounaris DN (2010) Five decades of business research into exporting: A bibliographic analysis. Journal of International Management 16(1): 78-91.

Leonidou LC, Palihawadana D, Chari S, et al. (2011) Drivers and outcomes of importer adaptation in international buyer-seller relationships. Journal of World Business 46: 527-543.

Love JH and Roper S (2015) SME innovation, exporting and growth: A review of existing evidence. International Small Business Journal: Researching Entrepreneurship 33(1): 28-48.

Meschi PX, Ricard A and Moore ET (2017) Fast and furious or slow and cautious? The joint impact of age at internationalisation, speed, and risk diversity on the survival of exporting firms. Journal of International Management 23(3): 279-291.

Miles MB and Huberman AM (1994) Qualitative Data Analysis: An Expanded Sourcebook. Thousand Oaks, CA: Sage.

Naidu GM and Rao TR (1993) Public sector promotion of exports: A need-based approach. Journal of Business Research 27: 85-101.

Narayanan V (2015) Export barriers for small and medium-sized enterprises: A literature review based on Leonidou's model. Entrepreneurial Business and Economics Review 3(2): 105-123.

Ojala A (2009) Internationalisation of knowledge-intensive SMEs: The role of network relationships in the entry to a psychically distant market. International Business Review 18(1): 50-59.

Olejnik E and Swoboda B (2012) SMEs'internationalisation patterns: Descriptives, dynamics and determinants. International Marketing Review 29(5): 466-495.

Pauluzzo R and Shen B (2018) The impacts of management on the international development of SMEs. In: Pauluzzo R and Shen B (eds) Impact of Culture on Management of Foreign SMEs in China. Cham: Springer International Publishing, pp.69-90.

Piekkari R, Welch C and Paavilainen E (2009) The case study as disciplinary convention: Evidence from international business journals. Organisational Research Methods 12(3): 567-589.

Prashantham S, Kumar K, Bhagavatula S, et al. (2018) Effectuation, network-building and internationalisation speed. International Small Business Journal: Researching Entrepreneurship 37(1): 3-21.

Ramsden M and Bennett RJ (2005) The benefits of external support to SMEs: 'Hard' versus 'soft' outcomes and satisfaction levels. Journal of Small Business and Enterprise Development 12(2): 227-243.

Ryan GW and Bernard HR (2000) Data management and analysis methods. In: Denzin NK and Lincoln YS (eds) Handbook of Qualitative Research (2nd edn). Thousand Oaks, CA: Sage, pp.769-802.

Sbrana R and Tangheroni MS (1991) Italian exporting SMFs and their use of support services. In: Seringhaus FHR and Rosson PF (eds) Export Development and Promotion: The Role of Public Organisations. Boston, MA: Springer, pp.145-160.

Seringhaus FHR (1987) The use of trade missions in foreign market entry. Industrial Marketing and Purchasing 2: 43-60.

Seringhaus FHR and Rosson PJ (1991) Export promotion and public organisations: The state of the art. In: Seringhaus FHR and Rosson PJ (eds) Export Development and Promotion: The Role of Public Organisations. Boston, MA: Kluwer Academic Publishers, pp.3-18. 
Singer TO and Czinkota MR (1994) Factors associated with effective use of export assistance. Journal of International Marketing 2(1): 53-71.

Sousa MP and Bradley F (2009) Effects of export assistance and distributor support on the performance of SMEs. International Small Business Journal: Researching Entrepreneurship 27(6): 681-701.

Spence MM (2003) Evaluating export promotion programmes: UK overseas trade missions and export performance. Small Business Economics 20: 83-103.

Tian YA, Nicholson JD, Eklinder-Frick J, et al. (2018) The interplay between social capital and international opportunities: A processual study of international 'take-off' episodes in Chinese SMEs. Industrial Marketing Management 70: 180-192.

Uner MM, Kocak A, Cavusgil E, et al. (2013) Do barriers to export vary for born globals and across stages of internationalisation? An empirical inquiry in the emerging market of Turkey. International Business Review 22(5): 800-813.

Vaccarini K, Lattemann C, Spigarelli F, et al. (2017) Chinese FDI and psychic distance perceptions on regulations in the German renewable energy sector. Energy Policy 101: 723-732.

Vahlne JE and Johanson J (2013) The Uppsala model on evolution of the multinational business enterprise - From internalization to coordination of networks. International Marketing Review 30(3): 189-210.

Welch LS and Wiedersheim-Paul F (1979) Export promotion policy - A new approach. Australian Journal of Management 4(2): 165-177.

Wright M, Roper S, Hart M, et al. (2015) Joining the dots: Building the evidence base for SMEs growth policy. International Small Business Journal: Researching Entrepreneurship 33(1): 3-11.

Yin RK (2009) Case Study Research: Design and Methods. Thousand Oaks, CA: Sage.

Yoo S-J, Mackenzie NG and Jones-Evans D (2012) Public sector support and technology-based SMEs in peripherical areas - The case of North Wales. Journal of Enterprising Culture 20(1): 83-104.

Zahra SA and George G (2002) International entrepreneurship: The current status of the field and future research agenda. In: Hitt MA, Ireland RD, Camp SM, et al. (eds) Strategic Entrepreneurship: Creating a New Mindset. Oxford: Blackwell Publishers, pp.255-288.

Zahra SA, Ireland RD and Hitt MA (2000) International expansion by new venture firms: International diversity, mode of market entry, technological learning, and performance. Academy of Management Journal 43(5): 925-950.

Zhang X, Ma X, Wang Y, et al. (2016) What drives the internationalisation of Chinese SMEs? The joint effects of international entrepreneurship characteristics, network ties, and firm ownership. International Business Review 25(2): 522-534.

\section{Author biographies}

Nathalie Belhoste is Assistant Professor and holds a PhD in Political Science from Sciences Po Paris. Her research focuses on the impact of international politics on international business. She has published in various journals such as Human Relations and Critical Perspectives on International Business.

Rachel Bocquet is Professor of Strategy and Innovation Management at University Savoie Mont Blanc (France). As a researcher at the IREGE institute, her field of research is centreed on the determinants of SMEs' innovation and growth. She has published several articles in books and international journals such as Journal of Small Business Management, Journal of Business Ethics and Research Policy.

Véronique Favre-Bonté is Professor of International and Innovation Management at University Savoie Mont Blanc (France). As a researcher at the IREGE institute, her field of research is centreed on international entrepreneurship. She has published in both entrepreneurship and management journals such as International Journal of Entrepreneurship and Small Business, European Management Review, and European Planning Studies.

Frédéric Bally is a PhD candidate in sociology at University Savoie Mont Blanc (France). His research investigates public participation in city development and planning through community gardening. He is a research associate at Grenoble Business School and works on SMEs internationalization and public support for entrepreneurship. 


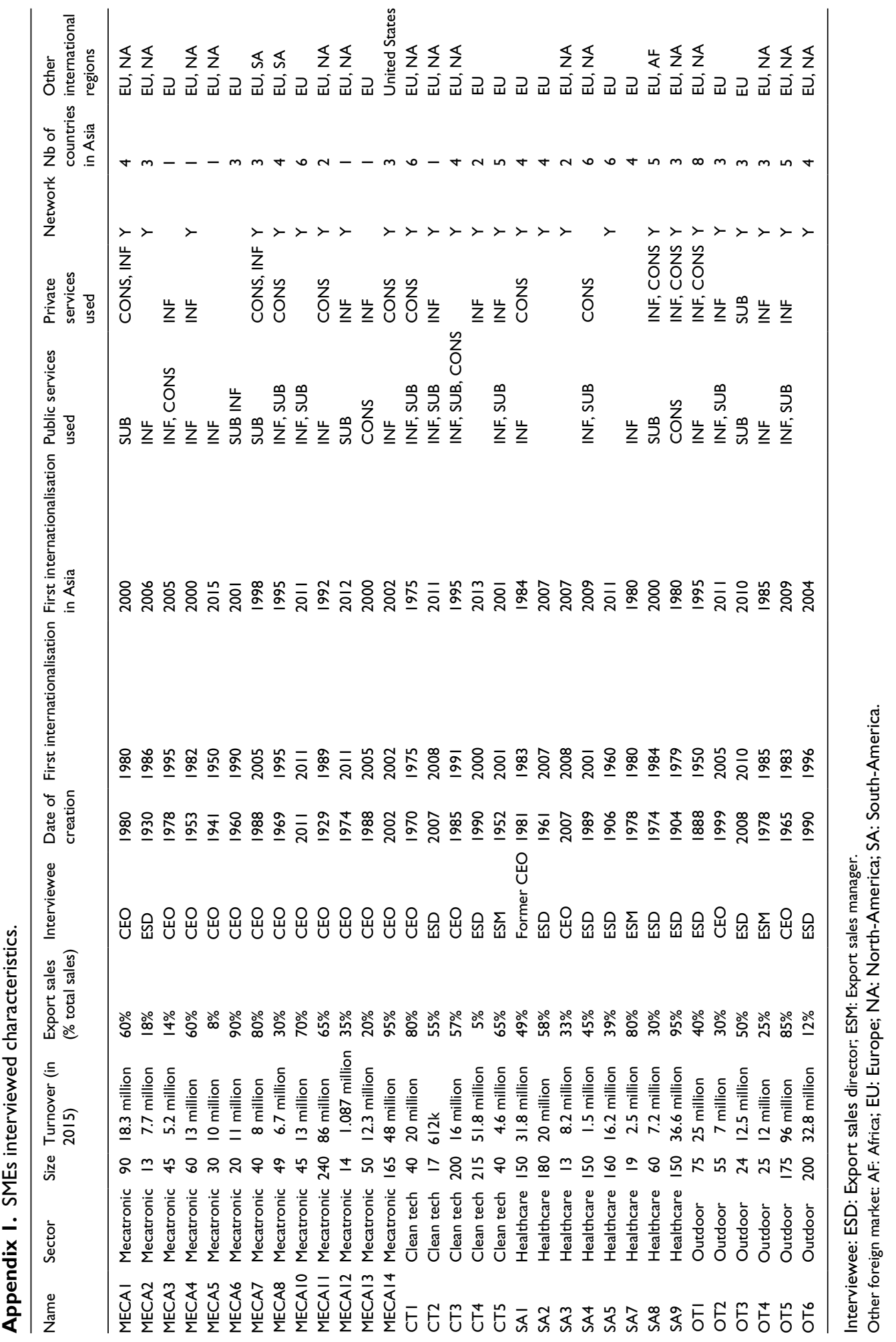




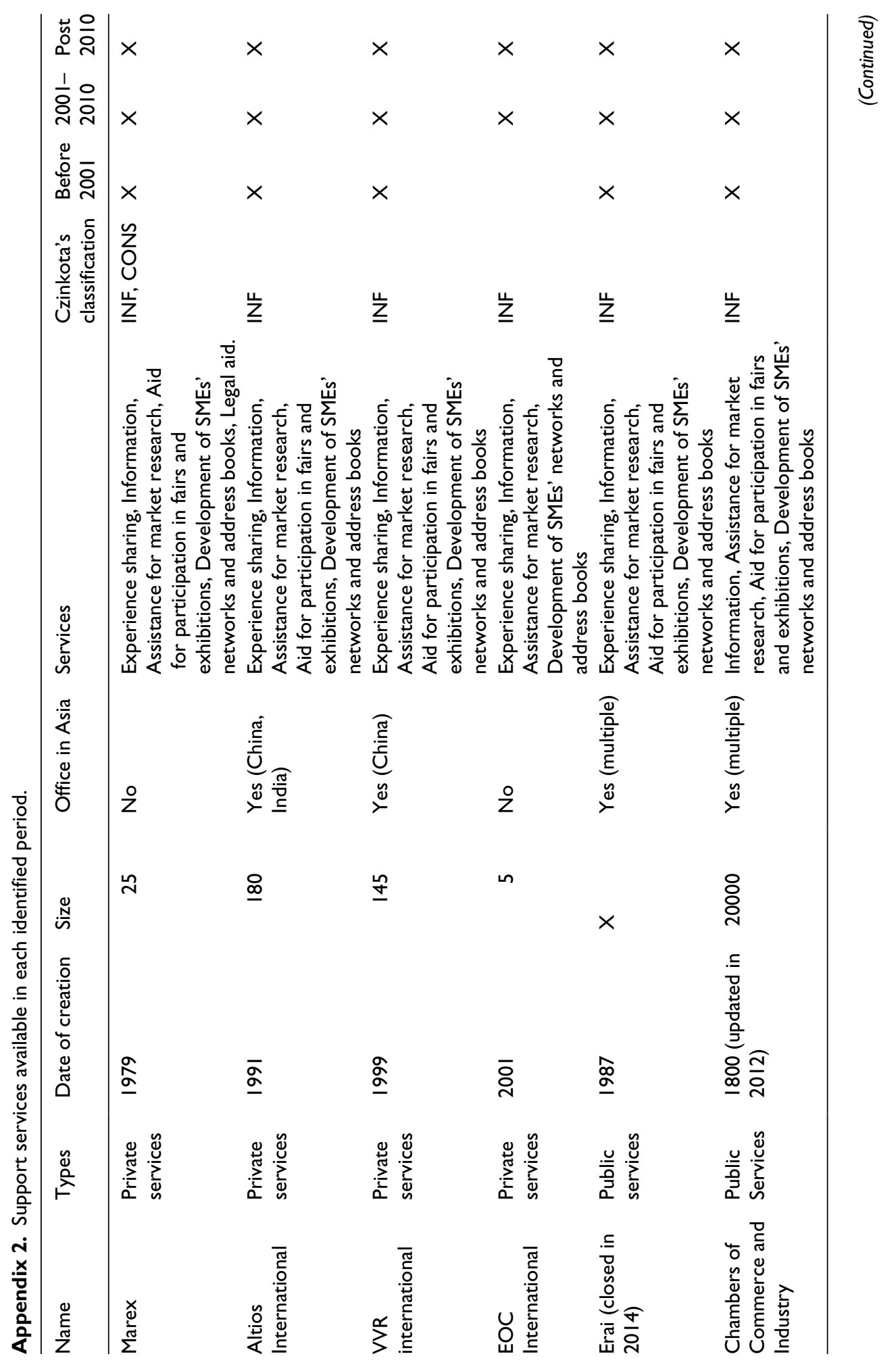




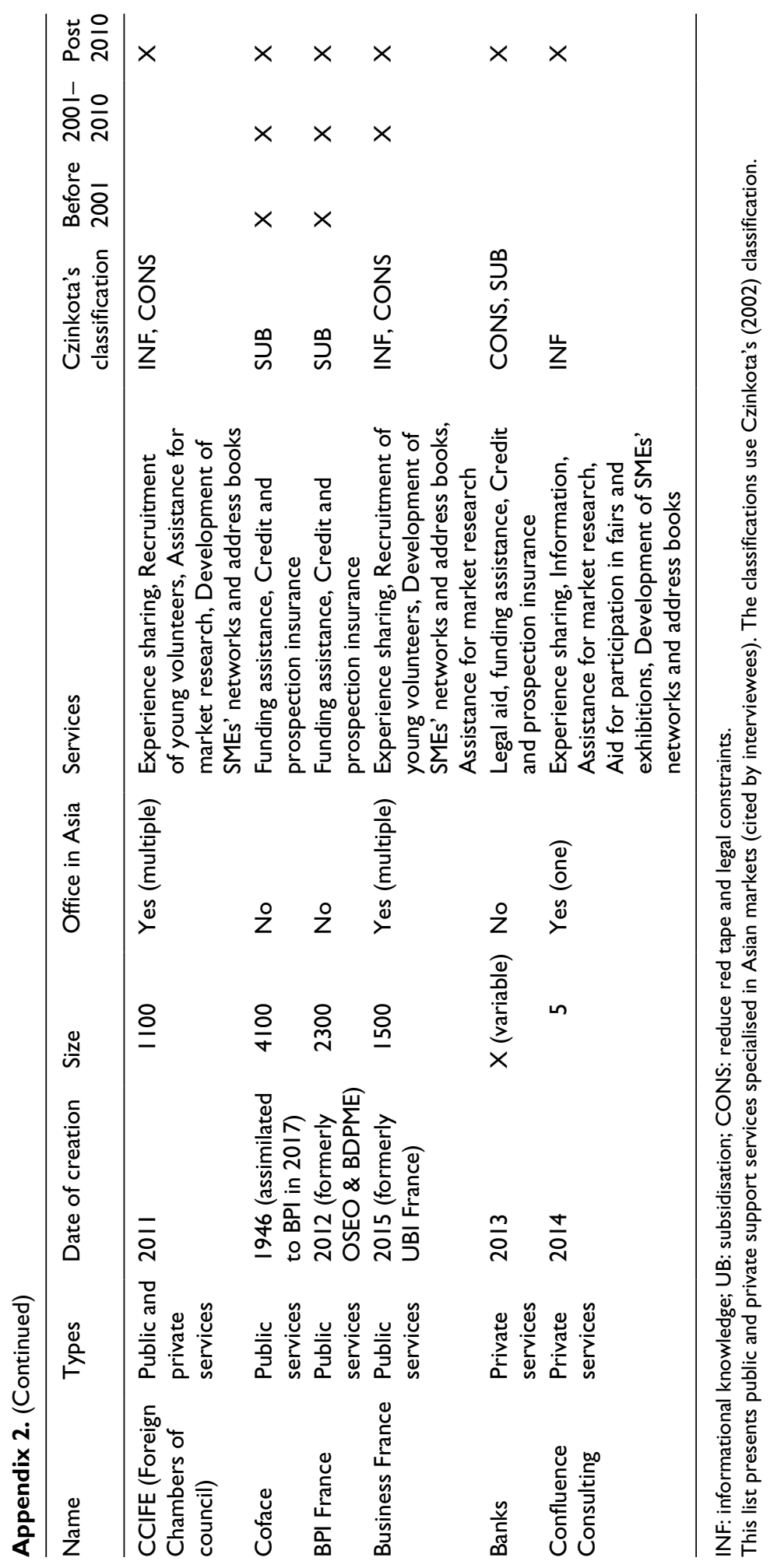


Appendix 3. Secondary data collected.

\begin{tabular}{|c|c|c|c|c|c|}
\hline Type & Report & Meeting & Website & Article & $\begin{array}{l}\text { Data from } \\
\text { organisation }\end{array}$ \\
\hline SMEs & $\begin{array}{l}\text { SMEs annual } \\
\text { report (when } \\
\text { available) }\end{array}$ & & $\begin{array}{l}\text { SMEs website } \\
\text { (historical, activities } \\
\text { and markets } \\
\text { if available), } \\
\text { Newsletter, BPI } \\
\text { Elite list of SMEs } \\
\text { supported, Business } \\
\text { France Website, } \\
\text { Coface Website }\end{array}$ & $\begin{array}{l}\text { Online } \\
\text { Newspapers } \\
\text { (Usine } \\
\text { Nouvelle, Le } \\
\text { Dauphiné. . .) }\end{array}$ & $\begin{array}{l}\mathrm{CCl} \text { data } \\
\text { for revenue } \\
\text { and size, } \\
\text { Societe.com, } \\
\text { Business } \\
\text { France (SMEs } \\
\text { supported) }\end{array}$ \\
\hline $\begin{array}{l}\text { Support } \\
\text { Services }\end{array}$ & $\begin{array}{l}\text { Annual report } \\
\text { of public } \\
\text { support } \\
\text { services (BPI, } \\
\text { Business France } \\
\text { and Coface) }\end{array}$ & $\begin{array}{l}\text { Meetings and conferences } \\
\text { promoting the public } \\
\text { support services to Asia, } \\
\text { Conferences by Support } \\
\text { services on the practices } \\
\text { to succeed in China, } \\
\text { OSCI Annual meeting } \\
(2017)\end{array}$ & $\begin{array}{l}\text { Support Services } \\
\text { Website (services } \\
\text { proposed and } \\
\text { implantation), } \\
\text { Newsletter }\end{array}$ & $\begin{array}{l}\text { Specialised } \\
\text { press (Class } \\
\text { Export) }\end{array}$ & $\begin{array}{l}\text { OSCI for } \\
\text { private } \\
\text { support } \\
\text { services } \\
\text { activities and } \\
\text { implantation }\end{array}$ \\
\hline
\end{tabular}

SMEs: small and medium-sized enterprises. 